\title{
Macrodactyly of the foot: a case report
}

\section{Macrodactilia do pé: relato de caso}

\author{
Arzac Ulla Ignacio ${ }^{1}$ \\ 1. BR Traumatologia, Província de Buenos Aires, Buenos Aires, Argentina.
}

\begin{abstract}
Macrodactyly is an uncommon congenital foot condition that can be difficult to treat and that can have a profound negative impact on patients and their families. Although many treatments have been described, results tend to be inconsistent. The author reports a case in which a combination of parcial bone and finger resection, resulted in a foot with acceptable function and cosmesis.
\end{abstract}

Level of Evidence V; Therapeutics Studies; Expert Opinion.

Keywords: Foot; Toes/surgery; Foot deformities, congenital; Gigantism/pathology.

\section{RESUMO}

A macrodactilia é uma condição congênita incomum do pé que pode ser difícil de tratar e pode ter um impacto negativo profundo nos pacientes e em suas famílias. Embora muitos tratamentos tenham sido relatados, os resultados podem ser inconsistentes. $\mathrm{O}$ autor relata um caso em que uma combinação de ressecção parcial dos ossos e dedos resultou em um pé com função e cosmese aceitável.

Nível de Evidência V; Estudos Terapêuticos; Opinião do Especialista.

Palavras-chave: Pé; Dedos do pé/cirurgia; Deformidades congênitas do pé; Gigantismo/patologia.

How to cite this article: Ignacio AU. Macrodactyly of the foot: a case report. Sci J Foot Ankle. 2019;13(4): 255-8.

\section{INTRODUCTION}

Macrodactyly is a rare congenital condition that involves the upper or lower limbs. It is characterized by the overgrowth of fingers or toes and it often leads to the amputation of one or more toes ${ }^{(1)}$. Barsky defines it as an entity in which the size of phalanges, tendons, nerves, vessels, subcutaneous fat, nails and skin is enlarged ${ }^{(1,2)}$. Although its etiology is not fully known, some studies claim that this condition is caused by abnormal neural control of the sensory distribution in a peripheral nerve ${ }^{3}$. Incidence of foot macrodactyly is $1 / 18,000^{(4)}$.
Despite being a benign condition, all tissues of the involved areas are abnormal. Bone structures are enlarged and deformed, joints become stiff and hyperostotic and the amount of adipose tissue is increased. Foot involvement results in gait disorders, inability to adapt to normal footwear, stiff toes, nail alterations, distal ulcers, osteomyelitis and aesthetic problems ${ }^{(5)}$.

Surgical treatment of this condition is diverse and includes resection of multiple phalanges, amputation, syndactylization, digit shortening, soft tissue debulking, osteotomies, etc. Early surgical intervention has been shown to be

Work performed at the BR Traumatologia, Província de Buenos Aires, Buenos Aires, Argentina

Correspondence: Arzac Ulla Ignacio. De Paula, 528, Azul, Província de Buenos Aires, Buenos Aires, Argentina. CEP: 7300.

E-mail: ignacioarzac@hotmail.com

Conflicts of interest: none. Source of funding: none.

Date received: September 12, 2019. Date accepted: December 17, 2019. Online: December 23, 2019. 
beneficial ${ }^{(6)}$. The goal of surgical reconstruction in macrodactyly is to obtain a functional limb with good cosmetic appearance.

The purpose of this report is to document this rare condition, its diagnosis, treatment and literature review.

\section{CASE REPORT}

This study was approved by the Ethics Committee of our institution.

A 36-year-old male patient, with no significant medical history or trauma, presented with a twenty-year history of two slowly progressive hypertrophic lesions, located in the third and fourth toes of the right foot (Figure 1). Physical examination showed an increase in the size of the toes. During complaint-directed history taking, the patient denied feeling pain but reported that the condition affected his daily activities.

Frontal, oblique and lateral radiographs of the foot were requested, which revealed enlargement and deformity of all phalanges of the third and fourth toes (Figure 2).

Diagnosis of macrodactyly was confirmed through clinical and radiological findings.

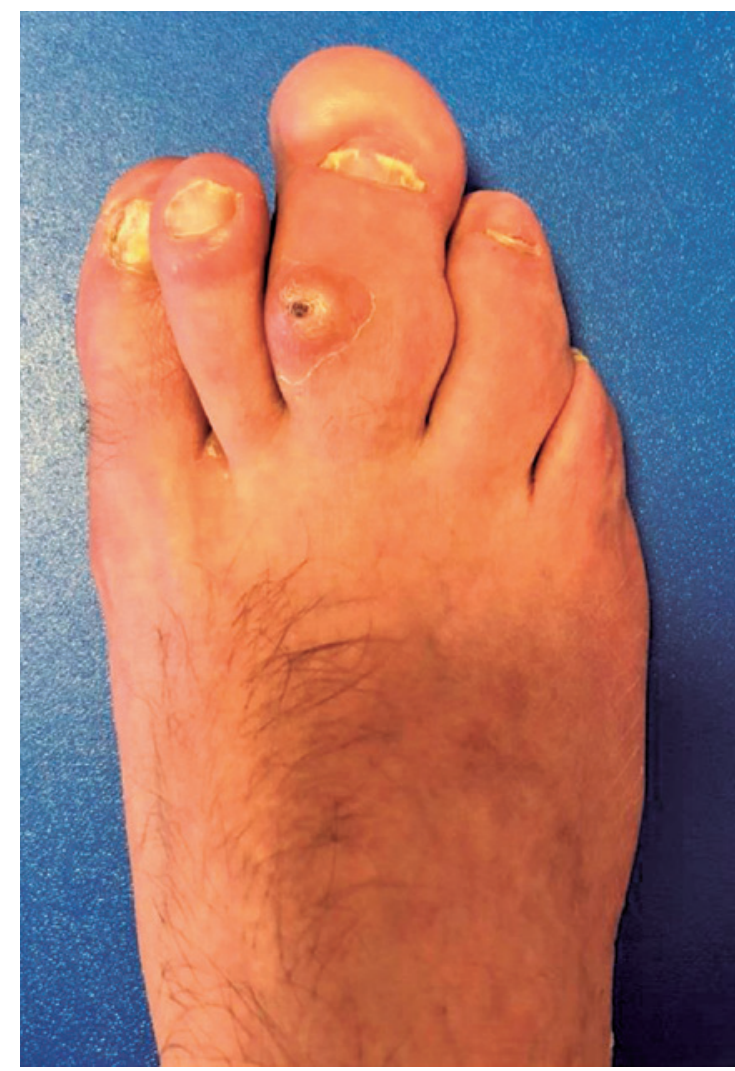

Figure 1. Photo before surgery.

Source: Author's personal archive.
All treatment options described in the literature were evaluated and forefoot remodeling was eventually considered to be the best alternative. The first surgical intervention consisted of reconstruction of the third toe, with resection of excessive adipose tissue, phalangeal remodeling and removal of excess skin (Figure 3 ).

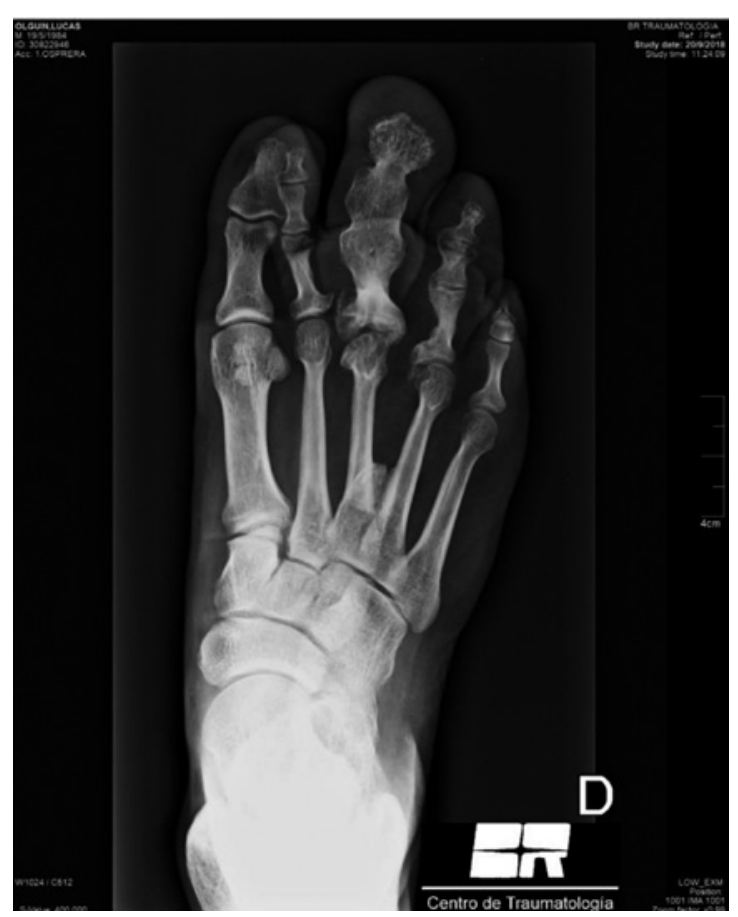

Figure 2. Pre-surgery radiography. Source: Author's personal archive.

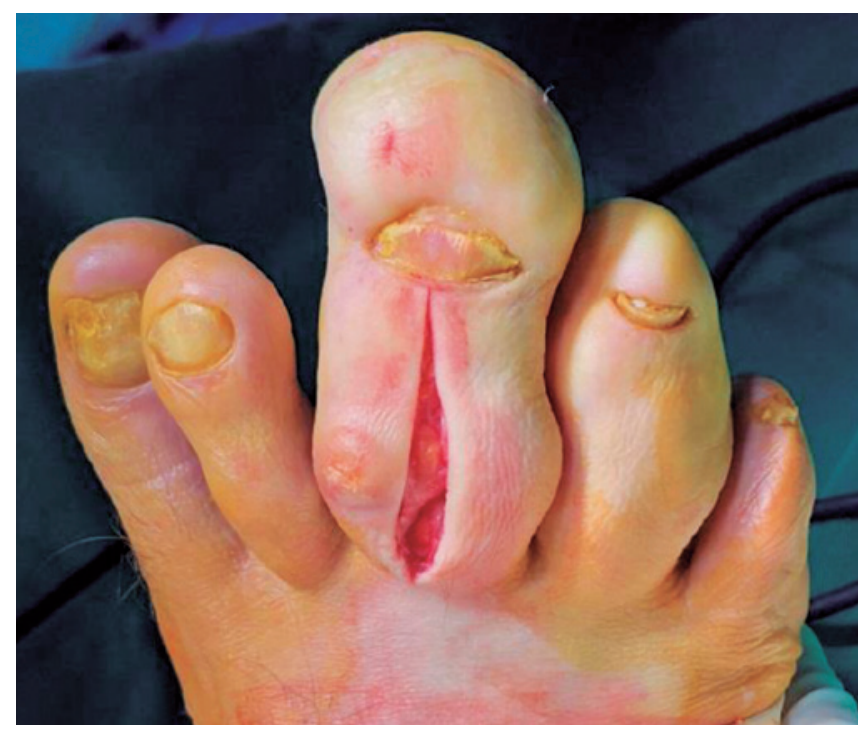

Figure 3. Longitudinal approach on third finger. Source: Author's personal archive. 
Soft tissue biopsies were obtained. Pathological findings included significant soft tissue thickening and fibroadipose tissue macrodystrophy (Figure 4).

Post-operative care included ciprofloxacin plus clindamycin for 7 days, cilostazol every 12 hours for 21 days, and wound cleaning with rubbing alcohol.

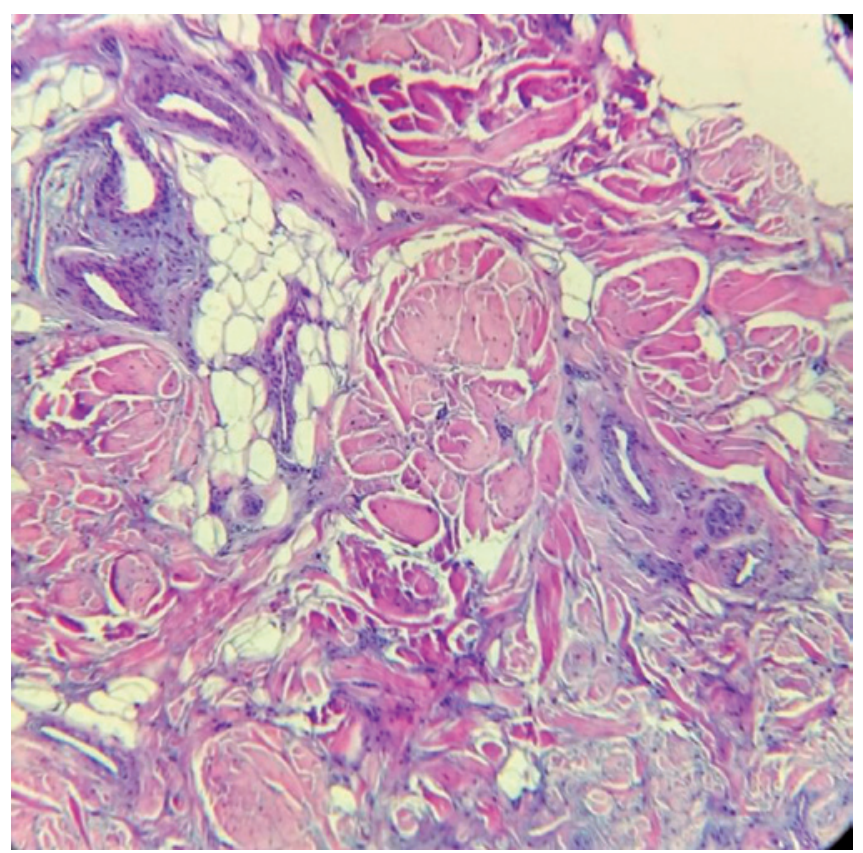

Figure 4. Pathological findings included significant soft tissue thickening and fibroadipose tissue macrodystrophy.

Source: Author's personal archive.

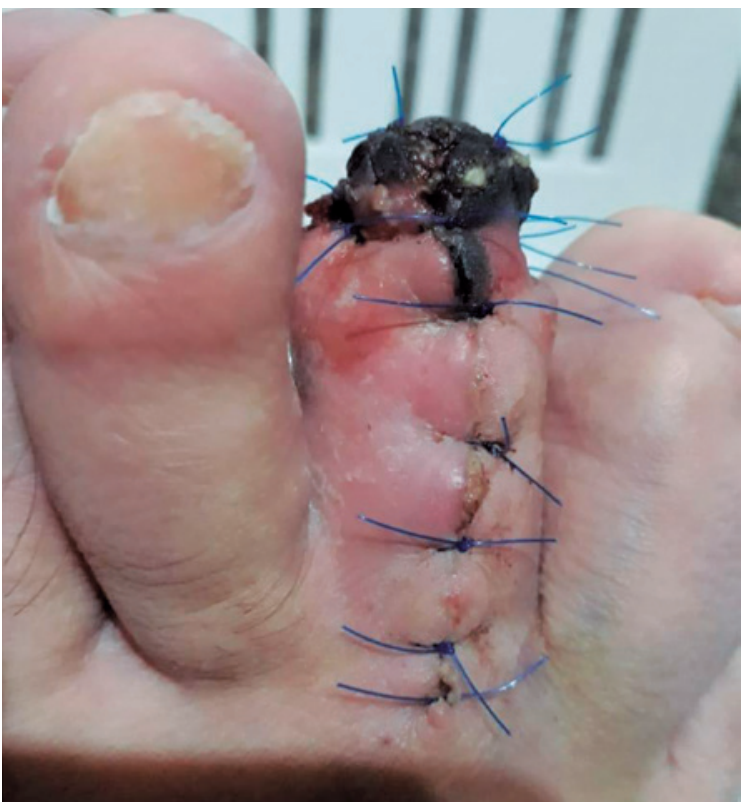

Figure 5. Post-operative distal finger necrosis.

Source: Author's personal archive.
The patient developed necrosis of the distal part of the third phalanx. However, underlying vascularized tissue was observed (Figure 5). The eschar became detached 40 days later, with good cosmetic and functional outcomes of the toe.

After complete healing of the third toe, the fourth toe was surgically corrected using the same procedure and post-operative protocol.

Progression was similar, resulting in necrosis of the third phalanx, which resolved completely within 40 days (Figure 6).

\section{DISCUSSION}

Macrodystrophia lipomatosa was described in 1925 by Feriz ${ }^{7}$. It is defined as a rare form of localized gigantism, characterized by a disproportionate increase of fibroadipose tissue ${ }^{(10)}$. Golding later extended this term to describe similar lesions of the hand ${ }^{(7)}$.

It is usually diagnosed at birth ${ }^{(1,3)}$ and has an equal sex ratio. However, in our case, the patient sought consultation when he reached adulthood.

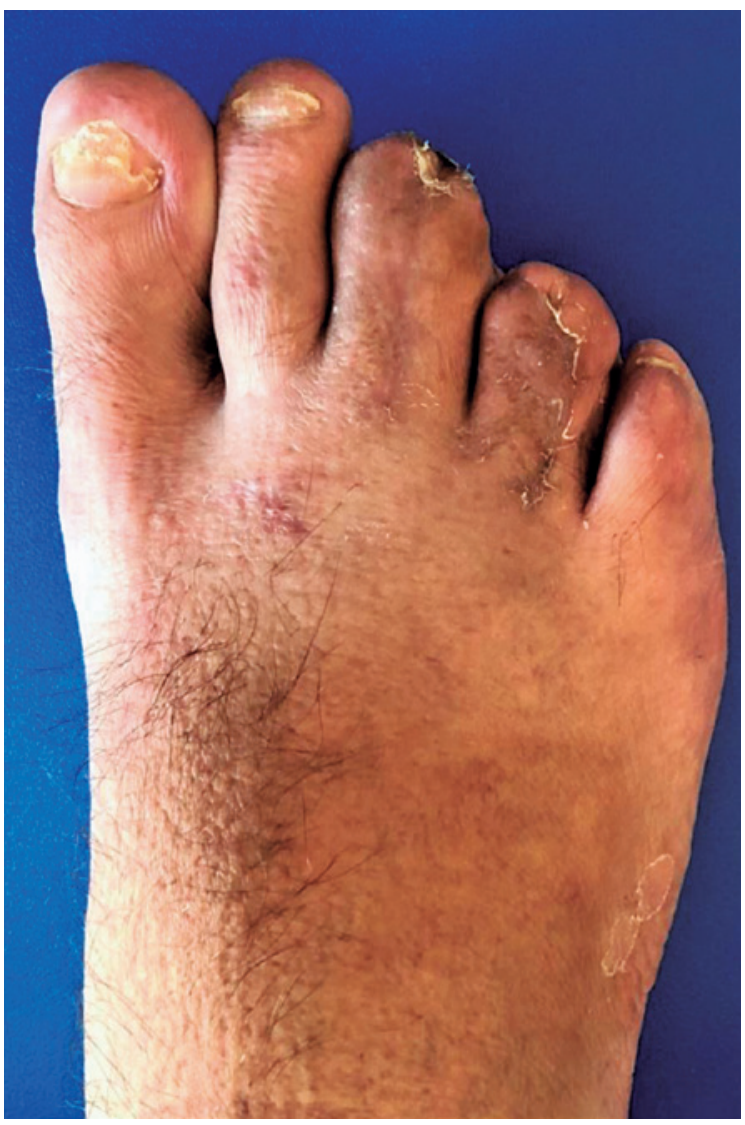

Figure 6. 40 days post-operative.

Source: Author's personal archive. 
Growth rate is variable and involvement is almost always unilateral. The lower extremities, namely the second and third toes, are most commonly affected ${ }^{(3,8)}$.

Two types of macrodactyly are typically distinguished static macrodactyly, which is observed at birth, with the involved limb growing proportionally to the child's development; and progressive macrodactyly, in which the affected digit grows at a faster rate than the rest of the body $y^{(1)}$.

Hardwicke et al. ${ }^{(9)}$ described four types of macrodactyly - type I, macrodactyly with lipofibromatosis of a nerve, either of a static or progressive subtype; type II, associated with neurofibromatosis; type III, associated with hyperostosis; and type IV, associated with hemihypertrophy.

Differential diagnoses include, but are not limited to, neurofibromatosis, Ollier's disease, Klippel-Trenaunay syndrome, Still's disease, dactylitis secondary to infections, trauma, and osteoid osteoma(9).

Regarding treatment, soft tissue resection as a single procedure is unsuccessful due to the high recurrence rate ${ }^{(5)}$.
Dedrick and Kling ${ }^{(10)}$ recommend ray amputation when the affected toe is two standard deviations above the length of the contralateral toe. Although our patient presented more than two standard deviations, reconstructive surgery was successful, with no recurrence or complications during the 18-month follow-up.

It should be noted that toe amputation is not free from complications, such as hallux valgus, wound dehiscence, recurrence, and prolonged edema, among others ${ }^{(2)}$.

\section{CONCLUSION}

This case report focuses on presenting a rare condition that is often underdiagnosed and highlights the importance of early diagnosis and treatment to avoid radical measures, such as amputation.

Ray resection should not be considered an unsuccessful management option for this condition, but we believe reconstructive surgery to be the best alternative for these patients.

Authors' contributions: Each author contributed individually and significantly to the development of this article: AUl *(https://orcid.org/0000-0002-50387720) conceived and planned the activities that led to the study, wrote the article, interpreted the results of the study, approved the final version. performed the surgery. ${ }^{*} \mathrm{ORCID}$ (Open Researcher and Contributor ID).

\section{REFERENCES}

1. Barsky AJ. Macrodactyly. J Bone Joint Surg 1967;49(7):1255-66.

2. Mariappan N, Subha D, Cheena G. Macrodactyly of lower limbs - an update. J Evolution Med Dent Sci. 2016;5(55):3806-10.

3. Kelikian H. Macrodactyly. In: Congenital deformities of the hand and forearm. Philadelphia, WB Saunders, 1974. p. 610-60.

4. Kowtharapu DN, Thawrani D, Kumar SJ. Macrodactyly. In: McCarthy JJ (editor) Drennen's the child's foot and ankle. $2^{\text {nd }}$ ed. Edn. Baltimore: Lippincot Williams and Wilkins; 2009. p. 443-9.

5. Chang CH, Kumar SJ, Riddle EC, Glutting J. Macrodactyly of the foot. J Bone Joint Surg Am. 2002;84(7):1189-94.
6. Alagar Raja D, Surya Rao Rao Venkata M. Macrodystrophia lipomatosa of the toe: a rare case report. J Clin Diagn Res. 2016;10(4):27-28.

7. Feriz H. Macrodystrophia lipomatosa progressiva. Virchow Arch Pathol Anat Klin Med 1925;260:308-68.

8. Thorne FL, Posch JL, Mladick RA. Megalodactyly. Plast Reconstr Surg. 1968;41(3):232-9.

9. Hardwicke J, Khan MA, Richards H, Warner RM, Lester R. Macrodactyly - Options and outcomes. J Hand Surg Eur Vol. 2013;38(3):297-303.

10. Dedrick D, Kling TF. Ray resection in the treatment of macrodactyly of the foot in children. Orthop Trans. 1985;9:145. 